\title{
Effect of prill fat supplementation on hormones, milk production and energy metabolites during mid lactation in crossbred cows
}

\author{
Mahendra Singh $^{1}$, J. P. Sehgal ${ }^{2}$, A. K. Roy ${ }^{1}$, S. Pandita ${ }^{1}$ and G. Rajesh ${ }^{3}$ \\ 1. Division of Animal Physiology, National Dairy Research Institute, Karnal, 132001 Haryana, India; \\ 2. Division of Animal Nutrition, National Dairy Research Institute, Karnal, 132001 Haryana, India; \\ 3. Division of Veterinary Physiology, Indian Veterinary Research Institute, Izatnagar - 243122, Uttar Pradesh, India \\ Corresponding author: Mahendra Singh, email: chhokar.ms@gmail.com \\ JPS: sehgaljp@rediffmail.com, AKR: royashwani@gmail.com, SP: sujata.pandita@rediffmail.com, \\ Received: 13-03-2014, Revised: 26-04-2014, Accepted: 03-05-2014, Published online: 09-06-2014
}

doi: $10.14202 /$ vetworld.2014.384-388

How to cite this article: Singh M, Sehgal JP, Roy AK, Pandita S and Rajesh G (2014) Effect of prill fat supplementation on hormones, milk production and energy metabolites during mid lactation in crossbred cows, Veterinary World 7(6): 384-388.

\begin{abstract}
Aim: To find out the effect of prill fat feeding on milk production and hormonal changes in crossbred cows.

Materials and Methods: Crossbred cows in mid lactation (150 days) were selected from the institutes' herd. The observations on dry matter intake (DMI), body weight, body condition score (BCS)were recorded and milk composition, plasma metabolites viz., glucose and Nonesterified fatty acids (NEFA) were measured in control (CON) and experimental prill fat group (PFG) cows. During the experimental period, PFG cows were fed with bypass prill fat @ $75 \mathrm{~g} / \mathrm{d}$ for a period of 90 days.
\end{abstract}

Results: The DMI and body weight of cows was non-significant $(\mathrm{P}>0.05)$ between the groups, but $\mathrm{BCS}$ of cows improved in the CON group. Crude protein and Total digestible nutrients (TDN) intake/kg body weight was more $(\mathrm{P}>0.05)$ in $\mathrm{PFG}$ over the $\mathrm{CON}$. Milk yield, plasma hormones - Growth hormone, triiodothyronine and thyroxine $\left(\mathrm{GH}, \mathrm{T}_{3}, \mathrm{~T}_{4}\right)$ was significantly lower in $\mathrm{CON}$ group over the PFG cows $(\mathrm{P}<0.05)$. However ghrelin and leptin levels were not affected. Milk fat, protein, lactose and cholesterol were similar in both the groups. Furthermore, plasma NEFA decreased $(\mathrm{P}<0.05)$ and glucose varied nonsignificantly between the groups.

Conclusion: It was concluded that prill fat supplementation can be used to augment milk production without influencing milk composition and plasma metabolites in crossbred cows.

Keywords: cows, energy metabolites, hormones, milk yield, prill fat.

\section{Introduction}

The ability of the dairy cows to increase daily energy intake depends on the net energy density of the diet. The daily Dry Matter Intake (DMI) is highly regulated by animal nutrient requirements, metabolic states, and the type and temporal absorption of fuels. Fat supplements from different sources, its form and type has different hypophagic effects [1]. Previous reports indicate that feeding of fatty acid (FA) supplements including calcium salts of palm FA linearly decreases DMI with increasing dietary concentration, whereas hydrogenated FA had no effect on DMI $[2,3]$. However, dietary fat feeding induces decrease in milk protein concentration in animals. Milk yield changes in by pass fat cows could be due to the changes in ruminal fermentation, endocrine signaling, or mammary nutrient metabolism [4]. A linear decrease in milk crude protein $(\mathrm{CP})$ yield with abomasal unsaturated fatty acid (FA) infusion [2] and a decrease in milk casein yield with $\mathrm{C} 18$ unsaturated FA infusion compared with saturated FA [4] indicated that FA profile has an important role in fat-stimulated decreased milk protein. The maintenance of lactation of dairy cows depends on the balanced feeding during postpartum period. It has

Copyright: The authors. This article is an open access article licensed under the terms of the Creative Commons Attribution License (http://creativecommons.org/licenses/by/2.0) which permits unrestricted use, distribution and reproduction in any medium, provided the work is properly cited. been found that hydrogenated palm oil triglyceride provide a better energy supply for high-yielding dairy cows in negative energy balance than calcium soaps of palm oil fatty acids around calving [4].

Prill fat is a non-hydrogenated vegetable oil and contains more than $85 \%$ palmitic acid with high melting point. Due to this reason it does not melt at low $\mathrm{pH}$, by pass rumen degradation and is digested in small intestine by lipase enzyme. Prill fat is prepared by liquefying mixture of fatty acid by spraying it under pressure into a cooled atmosphere. prill fat remain inert in the rumen and resist hydrolysis and association with the bacterial cells of feed particles. Thus total supplemented energy in diet of a lactating animal is available for the productive processes.

Considering the importance of prill fat as an energy source in diet of lactating animals, the present experiment was conducted to find out the effect of prill fat supplementation on plasma hormones and milk production in crossbred cows so that this technology, if proved beneficial, could be used to augment lactation under field and farm conditions.

\section{Materials and Methods}

Ethical approval: The experimental protocol was duly cleared by the Institute Animal Ethic Committee.

Experimental procedure: Experiment was conducted 
Table-1: Chemical composition of feeds and fodder (on \% DM basis)

\begin{tabular}{lccc}
\hline Parameter & Concentrate & Green Maize fodder & Wheat straw \\
\hline Organic matter & 90.45 & 84.27 & 89.33 \\
Crude protein & 21.65 & 6.56 & 1.84 \\
Ether extract & 4.48 & 8.66 & 82.54 \\
Total carbohydrate & 64.85 & 59.04 & 76.78 \\
Neutral detergent fiber & 28.00 & 40.56 & 78.00 \\
Acid detergent fiber & 11.56 & 18.48 & 48.51 \\
Hemicellulose & 16.44 & 29.49 \\
\hline
\end{tabular}

Table-2: Body weight, BCS and nutrients intake in control and prill fat fed (PFG) cows during mid lactation

\begin{tabular}{|c|c|c|}
\hline Particulars & Control & PFG \\
\hline Metabolic body weight $(\mathrm{kg})$ at day 0 & $85.83^{\mathrm{a}} \pm 2.81$ & $95.31^{b} \pm 1.96$ \\
\hline Metabolic body weight $(\mathrm{kg})$ at day 90 & $81.69^{\mathrm{a}} \pm 3.23$ & $91.70^{\mathrm{b}} \pm 3.84$ \\
\hline Body Condition Score at day 0 & $2.40^{\mathrm{a}} \pm 0.24$ & $3.20^{\mathrm{b}} \pm 0.17$ \\
\hline $\begin{array}{l}\text { Body Condition Score at day } 90 \\
\text { Total dry matter intake }(\mathrm{kg} / \mathrm{d})\end{array}$ & $\begin{array}{l}2.00^{\mathrm{b}} \pm 0.44 \\
14.25 \pm 0.04\end{array}$ & $\begin{array}{l}2.60^{\mathrm{a}} \pm 0.24 \\
14.27 \pm 0.05\end{array}$ \\
\hline $\begin{array}{l}\text { Dry Matter Intake }(\mathrm{kg} / 100 \mathrm{~kg} \mathrm{BW}) \\
\text { Total crude protein intake }(\mathrm{kg} / \mathrm{d})\end{array}$ & $\begin{array}{c}3.32^{\mathrm{a}} \pm 0.01 \\
1.75 \pm 0.01\end{array}$ & $\begin{array}{l}3.88^{b} \pm 0.01 \\
1.76 \pm 0.01\end{array}$ \\
\hline Crude Protein Intake (kg/100 kg BW) & $0.41^{\mathrm{a}} \pm 0.01$ & $0.48^{\mathrm{b}} \pm 0.01$ \\
\hline Total digestible nutrient intake (kg/d) & $11.09^{\mathrm{a}} \pm 0.03$ & $10.65^{\mathrm{b}} \pm 0.03$ \\
\hline Total digestible nutrient Intake (kg/100 kg BW) & $2.47^{\mathrm{a}} \pm 0.01$ & $2.92 b \pm 0.01$ \\
\hline
\end{tabular}

Means having different superscripts ${ }^{a, b}$ in a row differ $(P<0.05)$; day $0=$ day of start of experiment

on 10 lactating crossbred cows having parity average of 2.6 and producing $10.15 \mathrm{~kg} / \mathrm{d}$ milk yield during midlactation (150 \pm 5 days) in the month of hot and humid season. The cows were selected based on similar level of milk production.

The control (CON) and experimental cows (prill fat group (PFG) were fed green fodder (Berseem/ Sorghum) ad lib and was managed as per the routine management practices in a shed with asbestos roofing. Experimental cows were fed prill fat @ $75 \mathrm{~g} / \mathrm{d}$ for a period of 90 days (period II). Following this, the feeding was stopped and the effect of withdrawal was recorded on the milk yield of cows for a period of 30 days. Body weight, body condition score (BCS) and feed intake was recorded at weekly intervals. Blood samples were collected at weekly intervals and analyzed for plasma glucose (GOD /POD method), Nonesterified fatty acids (NEFA) and cholesterol. Plasma levels of hormones- ghrelin and leptin (M/s SPI Bio Co.), growth hormone (GH, M/s Cloud Clone Corp. USA), prolactin (M/s SPI Bio Co.) were estimated by enzyme immunoassay kits. Tri-iodothyronine $\left(\mathrm{T}_{3}\right)$, thyroxine, $\left(\mathrm{T}_{4}\right)$, insulin and cortisol levels were estimated by radio-immunoassay (RIA) kits (M/s Beckman Coulter $\mathrm{Co}$, Czech Republic). The intra-assay and inter-assay variations for ghrelin, leptin, $\mathrm{GH}, \mathrm{T}_{3}, \mathrm{~T}_{4}$, insulin and cortisol were $8.53,9.99,10.03,6.25,8.43,8.88$ and $7.56 \%$, and $12.99,13.45,14.56,11.67,10.89,13.98$ and $10.06 \%$, respectively. BHBA and triglycerides was estimated by kits (M/S Cayman Chem. Co.,). Milk fat, protein and lactose were estimated by Milkotester (M/S Meganetco). Total cholesterol was estimated by Span Diagnostic kit.

Statistical analysis: Data was analyzed using Sigma Stat32 programme with two-way ANOVA.

\section{Results}

Metabolic body weight at the beginning of experiment was more $(\mathrm{P}<0.05)$ in $\mathrm{CON}$ cows however after 90 days of experiment, metabolic weight increased significantly $(\mathrm{P}<0.05)$ in $\mathrm{PFG}$ cows.Body weight of both the group of cows declined at 90 days of lactation; however totals DMI was similar in both the groups (Table-1 and 2). The decline in BCS $(\mathrm{P}<0.01)$ was more in CON cows than the PFG cows. The dry matter intake and crude protein intake (kg/100 kg b.wt.) was significantly more $(\mathrm{P}<0.05)$ in $\mathrm{PFG}$ group in comparison to CON (Table-2). Total digestible nutrients (TDN) intake $(\mathrm{kg} / \mathrm{d})$ and TDN intake $(\mathrm{kg} / 100 \mathrm{~kg}$ b.wt.) was significantly higher $(\mathrm{P}<0.05)$ in $\mathrm{PFG}$ cows than the CON cows. Milk yields during supple-mental of 90 days increased@0.50 kg/d/cow in the supplemented cows (PFG) over the control (CON). However, fat corrected milk, (FCM) and fat corrected milk energy was similar. The Energy corrected milk yield $(\mathrm{kg} / \mathrm{d})$ was higher $(\mathrm{P}<0.05)$ in $\mathrm{PFG}$ in comparison to control. The milk yield of cows remained higher $(\mathrm{P}<0.05)$ even after the withdrawal of prill fat feeding @ $0.71 \mathrm{~kg} / \mathrm{d}$ in comparison to control. However milk fat, protein and lactose remain unchanged (Table-3). Milk cholesterol was marginally higher in PFG cows than the CON cows.

Blood glucose was similar in both the groups but NEFA levels decreased in PFG cows when compared to CON group. Plasma cholesterol increased $(p<0.01)$ and HDL decreased in prill fat supplemented cows over the CON cows, but the values did not reach statistically significant (Table-4). Plasma BHBA, and triglycerides levels were not affected $(\mathrm{P}>0.05)$ in both the groups. Plasma ghrelin and prolactin levels decreased nonsignificantly in $\mathrm{PFG}$ cows $(\mathrm{P}>0.05)$, while $\mathrm{GH}, \mathrm{T}_{3}$ and $\mathrm{T}_{4}$ increased $(\mathrm{P}<0.05)$ singificantly in $\mathrm{PFG}$ cows in comparison to CON cows (Table- 5). Prill fat feeding 
Table-3: Milk yield and composition in control and prill fat fed (PFG) cows during mid lactation

\begin{tabular}{lcc}
\hline Particulars & Control & PFG \\
\hline Milk yield and composition during feeding period (90 days) & $14.01 \pm 1.31$ & $14.46 \pm 0.81$ \\
Milk yield (kg/d) & $13.44^{\mathrm{a}} \pm 1.10$ & $14.18^{\mathrm{b}} \pm 0.78$ \\
ECM (kg/d) & $60.96 \pm 3.24$ & $63.20 \pm 3.49$ \\
FCM & $4.26 \pm 0.21$ & $4.43 \pm 0.24$ \\
FCME & $13.38^{\mathrm{a}} \pm 1.31$ & $14.09^{\mathrm{b}} \pm 0.81$ \\
Milk yield and composition after withdrawal (30 days) & $3.84 \pm 0.31$ & $4.11 \pm 0.34$ \\
Milk yield (kg/d) & $3.11^{\mathrm{a}} \pm 0.07$ & $3.24^{\mathrm{b}} \pm 0.07$ \\
Fat (\%) & $4.74^{\mathrm{a}} \pm 0.12$ & $4.90^{\mathrm{b}} \pm 0.12$ \\
Protein (\%) & $9.20^{\mathrm{a}} \pm 0.23$ & $9.45^{\mathrm{b}} \pm 0.19$ \\
Lactose (\%) & $18.59 \pm 1.35$ & $20.05 \pm 1.44$ \\
Solid-not-fat (\%) & & \\
M. Cholesterol (mg/dL) & & \\
\hline
\end{tabular}

Means having different superscripts ${ }^{a, b}$ in a row differ $(P<0.05)$.

Table-4: Mean( \pm standard error) plasma concentrations of plasma parameters in control and prill fat fed (PFG) cows during mid lactation

\begin{tabular}{lcc}
\hline Particulars & Control & PFG \\
\hline Blood glucose $(\mathrm{mg} / \mathrm{dl})$ & $57.36 \pm 2.36$ & $55.19 \pm 3.06$ \\
Non-esterified fatty acids $(\mu \mathrm{M} / \mathrm{L})$ & $0.20 \pm 0.03^{\mathrm{a}}$ & $0.14 \pm 0.03^{\mathrm{b}}$ \\
B-hydroxy butyrate $(\mathrm{mM} / \mathrm{L})$ & $0.57 \pm 0.04$ & $0.60 \pm 0.08$ \\
Triglycerides $(\mathrm{mg} / \mathrm{dl})$ & $31.47 \pm 2.04$ & $25.96 \pm 1.24$ \\
Plasma cholesterol $(\mathrm{mg} / \mathrm{dl})$ & $169.37 \pm 11.31$ & $176.94 \pm 12.16$ \\
HDL-Cholesterol $(\mathrm{mg} / \mathrm{dl})$ & $88.32 \pm 3.31$ & $80.08 \pm 2.33$ \\
VLDL-Cholesterol $(\mathrm{mg} / \mathrm{dl})$ & $80.54^{\mathrm{a}} \pm 3.07$ & $86.13^{\mathrm{b}} \pm 3.26$ \\
\hline
\end{tabular}

Means having different superscripts ${ }^{a, b}$ in a row differ $(P<0.05)$.

Table-5: Mean( \pm standard error) plasma hormones level in control and prill fat fed (PFG) cows during mid lactation

\begin{tabular}{lcc}
\hline Hormones & Control & PFG \\
\hline Ghrelin $(\mathrm{pg} / \mathrm{dl})$ & $11.39 \pm 0.55$ & $9.10 \pm 0.68$ \\
Prolactin $(\mathrm{ng} / \mathrm{ml})$ & $19.18 \pm 1.08$ & $17.11 \pm 1.40$ \\
Growth hormone $(\mathrm{ng} / \mathrm{ml})$ & $1.87^{\mathrm{a}} \pm 0.12$ & $2.29^{\mathrm{b}} \pm 0.13$ \\
Cortisol $(\mathrm{ng} / \mathrm{ml})$ & $18.58 \pm 0.47$ & $18.00 \pm 1.55$ \\
T4 $(\mathrm{ng} / \mathrm{ml})$ & $38.41^{\mathrm{a}} \pm 1.96$ & $41.83^{\mathrm{b}} \pm 2.30$ \\
T3 $(\mathrm{ng} / \mathrm{ml})$ & $1.55^{\mathrm{a}} \pm 0.10$ & $1.78^{\mathrm{b}} \pm 0.12$ \\
Leptin $(\mathrm{ng} / \mathrm{ml})$ & $2.66 \pm 0.16$ & $2.92 \pm 0.04$ \\
Insulin $(\mu \mathrm{l} / \mathrm{ml})$ & $17.39 \pm 0.96$ & $17.72 \pm 1.58$ \\
\hline
\end{tabular}

Means having different superscripts ${ }^{a, b}$ in a row differ $(P<0.05)$.

did not affect plasma insulin levels in both the groups. Prill fat feeding incurred extra cost of Rs. 8/day/animal during the experimental period and generated additional income of Rs.50/day/animal by increased milk and fat yield. The total income return from the experimental prill fat fed cows was significantly more $(\mathrm{P}<0.05)$ in this study.

\section{Discussion}

The increased milk yield during prill fat feeding and thereafter, clearly elucidated the beneficial effect of prill fat on milk yield of cows in mid-lactation. The increase in milk yield was attributed to increase in galactopoietic hormone levels such as $\mathrm{GH}, \mathrm{T}_{3}$ and $\mathrm{T}_{4}$ in conjunction with higher dry matter intake in fat supplemented cows $[4,5]$, however decline in dry matter intake during mid lactation have been also reported [6]. The non-significant changes in plasma ghrelin, leptin and insulin further revealed that these hormones did not play a role in milk secretion during mid lactation. These results suggest that the mode of action of prill fat could be due to availability of more energy through the fatty acids to the mammary gland. The increase in plasma GH concentrations in this study is in agreement with the earlier reports in cows [1]. An increase in milk yield and NEFA level to the extent of over $20 \%$ in FA supplemented cows in comparison to un-supplemented cows have been reported due to improved energy balance of cows $(89.3 \mathrm{vs} .15 .5 \mathrm{Eq} / \mathrm{L}$, $\mathrm{p}<0.001)$ [1]. This fact is further evident from the improved BW and BCS of experimental cows. Contrary to this, lack of effects of bypass fat feeding on $\mathrm{BW}, \mathrm{BCS}$ or plasma ghrelin and growth hormone concentrations have revealed that cows did not change energy balance when fed with FA supplement [7]. Furthermore, prill fat did not affect plasma glucose and BHBA levels as glucose metabolism and hepatic gene expression related to gluconeogenic activity are not significantly affected [8]. Cows having higher liver fat content but did not develop fatty liver syndrome during the periparturient period may not compromise gene expression of gluconeogenic enzymes in liver [9]. The non-significant variation in blood metabolites in both the groups further confirms role of prill fat in augmen- 
ting milk production during established lactation and corroborates the earlier report in buffaloes [10].

The mild changes in leptin and ghrelin concentration in prill fat fed group of cows indicate that appetite of the cows was not adversely affected by treatment as evidence from the similar dry matter intake, though dietary fat lower leptin in the feedlot steers despite greater energy intake and body weight $[11,12]$. It has been reported that insulin-like growth factor-I and insulin decrease with dietary fat supplementation and the response of prill fat depends on physiological state of the animal, including age and sex [13]. Due to this reason either increase in $\mathrm{GH}$ and insulin [11, 14] or diminished level of insulin [7] and no effect of prill fat feeding on GH have been reported [11]. There is longterm regulation of leptin via nutritional status and short-term regulation by food intake [15]. It has been shown that fat feeding increases plasma leptin concentration in rats, depending on total energy intake and type of fat [12] but no effect of fat ingestion on leptin levels have been found in ruminant [14]. In lambs, leptin concentration increases through rumen bypass fat supplementation [16] due to metabolic modifications which occur mainly at hepatic and adipose tissue levels $[14,17]$. Thus feeding of prill fat augmented milk production and improve socioeconomic status of the small and medium dairy farmers $[18,19]$. The Technology of bypass fat protects the nutrient from degradation and biohydrogenation in rumen with increases in the energy density of diet, thus enabling the animals to meet their energy and essential fatty acid requirements expressing their milk production potential to the fullest extent [20].

\section{Conclusion}

The supplementation of prill fat can be used to augment lactation performance without affecting milk composition, plasma metabolites and hormonal levels in dairy cows. Furthermore, the effect of prill fat feeding on milk yield was found to be long lasting and cost effective.

\section{Authors' contributions}

MS: supervised the experimental work, feeding of prill fat and analysis of the samples collected during the experiment as Principal Investigator. JPS assisted in the collection and analysis of feed samples. AKR and SP assisted in collection and analysis of milk samples etc. GR estimated plasma hormones and helped in statistical analysis of data. All authors read and approved the final manuscript.

\section{Acknowledgements}

The authors are thankful to the Director, National Dairy Research Institute, Karnal Haryana for providing the necessary facilities to carry out this investigation. We are also thankful to the Board of Research in Nuclear Science / Bhaba Atomic Research Centre, (BRNS/BARC) Mumbai, India for providing the necessary funds in the project No.2013/35/48/ BRNS to carry out this investigation.

\section{Competing interests}

The authors declare that they have no competing interests.

\section{References}

1. Allen M. S. (2000) Effects of diet on short-term regulation of feed intake by lactating dairy cattle, J. Dairy Sci., 83: $1598-1624$.

2. Christensen R. A., Drackley J. K., LaCount D. W. and Clark J. H. (1994) Infusion of four long-chain fatty acid mixtures into the abomasum of lactating dairy cows, J. Dairy Sci., 77:1052-1069.

3. Bremmer D. R., Ruppert L. D., Clark J. H. and Drackley J. K. (1998) Effects of chain length and unsaturation of fatty acid mixtures infused into the abomasum of lactating dairy cows, J. Dairy Sci.,81:176-188.

4. Karcagi RG, Gaál T., Ribiczey P., Huszenicza G. and Husveth F. (2010) Milk production, peripartal liver triglyceride concentration and plasma metabolites of dairy cows fed diets supplemented with calcium soaps or hydrogenated triglycerides of palm oil, J. Dairy Res, 77: 151-158.

5. Duske K., Hammon H.M., Langhof A.K., Bellmann O., Losand B., Nürnberg K., Nürnberg G., Sauerwein H., Seyfert H.M. and Metges C.C. (2009) Metabolism and lactation performance in dairy cows fed a diet containing rumen-protected fat during the last twelve weeks of gestation, J. Dairy Sci., 92:1670-1684.

6. Weiss W. P. and Pinos-Rodríguez J.M. (2009) Production responses of dairy cows when fed supplemental fat in lowand high-forage diets, J. Dairy Sci., 92:6144-6155.

7. Harvatine K.. J. and Allen M. S. (2005) The Effect of Production Level on Feed Intake, Milk Yield, and Endocrine Responses to Two Fatty Acid Supplements in Lactating Cows, J. Dairy Sci., 88:4018-4027.

8. Lohrenz A.K., Duske K., Schneider F., Nürnberg K., Losand B., Seyfert H.M., Metges C.C.and Hammon H.M. (2010) Milk performance and glucose metabolism in dairy cows fed rumen-protected fat during mid lactation, J. Dairy Sci., 93 :5867-5876.

9. Hammon H. M., Stürmer G., Schneider F., Tuchscherer A., Blum H., Engelhard T., Genzel A., Staufenbiel R. and Kanitz W. (2009) Performance and metabolic and endocrine changes with emphasis on glucose metabolism in highyielding dairy cows with high and low fat content in liver after calving, J. Dairy Sci., 92:1554-1566.

10. Shelke S.K., Thakur S.S. and Amrutkar S.A.(2012) Effect of feeding protected fat and proteins on milk production, composition and nutrient utilization in Murrah buffaloes (Bubalus bubalis), Anim. Feed Sci. \& Technol., 171:98-107.

11. 11. Lammoglia M.A., Bellows R.A. and Grings E.E. (2000) Effects of dietary fat and sire breed on puberty, weight, and reproductive traits of F1 beef heifers, J. Anim. Sci., 78: 2244-2252.

12. Cha M.C. and Jones P.J. (1998) Dietary fat type and energy restriction interactively influence plasma leptin concentration in rats, J. Lipid. Res., 39:1655-1660.

13. Becú-Villalobos D., García-Tornadú I. and Lacau-Mengido I.M. (2007) Effect of fat supplementation on leptin, insulinlike growth factor I, growth hormone, Can. J. Vet. Res. 71: 218-225.

14. Chilliard Y., Bonnet M and Delavaud C. (2001) Leptin in ruminants Gene expression in adipose tissue and mammary gland, and regulation of plasma concentration, Domest. Anim. Endocrinol., 21:271-295.

15. Choi B.R., Palmquist D.L and Allen M.S. (2000) Cholecystokinin mediates depression of feed intake in dairy cattle fed high fat diets, Domest Anim. Endocrinol., 19: 159-175.

16. Yildiz S., Blache D. and Celebi F. (2003) Effects of short- 
term high carbohydrate or fat intakes on leptin, growth hormone and luteinizing hormone secretions in prepubertal fat-tailed Tuj lambs, Reprod. Domest. Anim., 38:182-186.

17. Grum D.E., Drackley J.K., Hansen L.R. and Cremin J. D., Jr. (1996) Production, digestion, and hepatic lipid metabolism of dairy cows fed increased energy from fat or concentrate, $J$. Dairy Sci., 79:1836-1849.

18. Vahora S.G., Parnerkar S. and Kore K.B. (2013) Productive efficiency of buffalo fed by pass fat under filed condions: Effect on milk yield, milk comostion, body weight and economics, Iranian J. Appl. Anim. Sci., 3:53-58.

19. Parnerkar S., Kumar D., Shankpal S.S and Thube H. (2010) Effect of feeding of bypass fat to lactating buffaloes during early lactation, pp 126-131 in Proc. of $7^{\text {th }}$ Biennial Anim. Nutr. Assoc. Conf., Orissa Univ. Agric and Technol., Bhubaneswar, India.

20. Krishna Mohan D.V.G. and Reddy Y.R. (2009) Role of bypass nutrients in small holder animal production Anim. Nutr. Assoc. World Conf., NASS Complex, ICAR New Delhi, p45-48.

$* * * * * * * *$ 